DE

M E D I C I N A

T R O P I C A L

DE

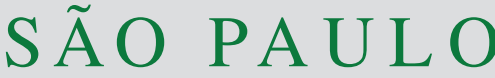

JOURNAL OF THE SÃO PAULO INSTITUTE OF TROPICAL MEDICINE

${ }^{1}$ Universidade de São Paulo, Faculdade de Zootecnia e Engenharia de Alimentos, Departamento de Medicina Veterinária, Laboratório de Medicina Veterinária Preventiva Aplicada, Pirassununga, São Paulo, Brazil

2Universidade de São Paulo, Faculdade de Medicina Veterinária e Zootecnia, Departamento de Medicina Veterinária Preventiva e Saúde Animal, Programa de Pós-Graduação em Epidemiologia Experimental Aplicada às Zoonoses, Pirassununga, São Paulo, Brazil

${ }^{3}$ Universidade de São Paulo, Faculdade de Zootecnia e Engenharia de Alimentos, Departamento de Medicina Veterinária, Programa de Pós-Graduação em Biociência Animal, Pirassununga, São Paulo, Brazil

${ }^{4}$ Universidade de São Paulo, Faculdade de Zootecnia e Engenharia de Alimentos, Departamento de Zootecnia, Pirassununga, São Paulo, Brazil

${ }^{5}$ Universidade de São Paulo, Faculdade de Medicina Veterinária e Zootecnia, Departamento de Medicina Veterinária Preventiva e Saúde Animal, Pirassununga, São Paulo, Brazil

Correspondence to: Trícia Maria Ferreira de Sousa Oliveira

Universidade de São Paulo, Faculdade de Zootecnia e Engenharia de Alimentos, Departamento de Medicina Veterinária, Avenida Duque de Caxias Norte, 225, CEP 13635006, Pirassununga, SP, Brazil

E-mail: tricia@usp.br

Received: 14 September 2020

Accepted: 14 December 2020

\section{Detection of Leishmania infantum DNA in blood samples of horses (Equus caballus) and donkeys (Equus asinus) by PCR}

\author{
João Augusto Franco Leonel ${ }^{(1,2}$, Bruna Tannihão', Julia Assis Arantes ${ }^{(1)} 3$, \\ Geovanna Vioti ${ }^{\circledR 1,2}$, Julia Cristina Benassi' ${ }^{1}$, Roberta Ariboni Brandi ${ }^{\circledR}$, \\ Helena Lage Ferreira ${ }^{(1,2}$, Lara Borges Keid ${ }^{(1,2}$, Rodrigo Martins \\ Soares ${ }^{2,5}$, Trícia Maria Ferreira de Sousa Oliveira ${ }^{1,2}$
}

\section{ABSTRACT}

Visceral leishmaniasis (VL) is a neglected tropical disease caused by the Leishmania infantum parasite. The protozoan is able to infect several domestic and wild mammals. Since the first report on Leishmania spp. infection in horses in South America, leishmaniasis in equids has been highlighted in Brazil. A molecular epidemiological survey was carried out to verify the occurrence of Leishmania spp. DNA in horses and donkeys, in leishmaniases endemic areas in Sao Paulo State, Brazil. To this end, blood samples were obtained from 107 horses and 36 donkeys and subjected to DNA extraction followed by PCR targeting the ITS-1 region. Among the horses and donkeys, $1.87 \%(2 / 107)$ and $8.33 \%(3 / 36)$ were positive by PCR, respectively. The DNA sequencing of the ITS-1 amplification products confirmed L. infantum DNA in these animals. Our results suggest that horses and donkeys from non-VL and VL endemic areas of São Paulo State may be infected by the parasite.

KEYWORDS: Asinines. Equines. Equids. Leishmania infantum. ITS-1. PCR.

\section{INTRODUCTION}

Leishmaniases are vector-borne infectious diseases that can manifest in several mammals, including humans ${ }^{1}$. They are caused by protozoans of the genus Leishmania and are transmitted by different genera of Phlebotomine sandflies ${ }^{2}$. The diseases are endemic in several countries, including Brazil, which presents the majority of cases in South America, and is the only country that has a high burden of the two clinical forms of disease ${ }^{1}$. Cutaneous (CL) and visceral leishmaniasis (VL) are the main manifestations of the disease in humans, according to Leishmania species infection ${ }^{2}$.

Horses infected by L. braziliensis were first described in South America in $1927^{3}$. Alencar, in 1959, described the first infection of the same parasite in donkeys from Brazi $^{4}$. Since then, cases of L. braziliensis infecting horses and donkeys have been described $^{4-13}$, with some authors suggesting their participation as primary reservoirs in the CL transmission cycle 10,11,13. $^{13}$.

Although dogs are considered the main L. infantum reservoir in the zoonotic VL cycle, some studies have shown that other mammals, such as cats and horses, can be infected by the parasite, developing symptomatic disease or remaining asymptomatic ${ }^{14,15}$. In fact, leishmaniasis in equids caused by $L$. infantum has also been confirmed in European countries ${ }^{16,17}$. In South America, L. infantum infection in horses was reported for the first time in two animals from Brazil, with skin 
lesions and locomotor problems ${ }^{14}$, followed by Benassi et $a l .{ }^{18}$ who described the first case of $L$. infantum infection in two asymptomatic horses in Sao Paulo State. To date, the epidemiological magnitude and impact of L. infantum infection in equids remains uncertain.

The diagnosis of Leishmania spp. infection in equids is generally based on parasitological, serological or molecular approaches ${ }^{19,20}$. The microscopic observation of the parasite within macrophages in tissue smears stained by Giemsa is considered the gold standard for the diagnosis ${ }^{19,20}$. However, the low sensitivity of direct microscopy is the main limitation of this technique ${ }^{10}$. Serological tests, such as the immunofluorescence antibody test (IFAT), immunoenzymatic assays (ELISA), and the direct agglutination test (DAT) are often used to detect antiLeishmania spp. antibodies in equids ${ }^{14,17-20}$. Nevertheless, deficiencies regarding sensitivity (due to low antibody levels) and specificity (due to cross-reactions between Leishmania spp. and other trypanosomatids parasites) have also been reported ${ }^{20}$. In this sense, molecular techniques such as PCR followed by sequencing, help on diagnosis confirmation and identification of infectious Leishmania species in equids ${ }^{14,17,18,20}$.

Taking into account all these facts, the aim of this study was to perform an epidemiological molecular survey to verify the occurrence of Leishmania spp. DNA in horses and donkeys, from endemic areas of both, CL and VL, in Sao Paulo State, Brazil.

\section{MATERIAL AND METHODS}

\section{Study area and sample collection}

This study was carried out in the equid population of Pirassununga city (CL endemic area) and Jau city (CL and VL endemic area), both counties of Sao Paulo State, Brazil. A convenience samples was composed of 107 horses from Pirassununga and 36 donkeys from Jau, between 2016 and 2017. Approximately $5 \mathrm{~mL}$ of blood were collected from the jugular vein of the animals, and thereafter they were submitted to DNA extraction. No clinical assessment was performed in these animals.

\section{Ethical issues}

The study was approved by the Ethics Committee for the Use of Animals at the Faculty of Animal Science and Food Engineering of the University of Sao Paulo (under the process $\mathrm{N}^{\circ} 3615240516$ and 8335160218 ) and was performed in compliance with national guidelines. All horse owners consented to have their animals sampled.

\section{DNA extraction}

DNA extraction from blood samples was performed using the Illustra ${ }^{\mathrm{TM}}$ Blood Genomic Prep Mini Spin kit (GE Healthcare Life Sciences, Uppsala, Sweden), according to the manufacturer's recommendations. The DNA samples were stored at $-20{ }^{\circ} \mathrm{C}$ until the amplification.

\section{Endogenous gene control}

To exclude false negatives due to DNA sample degradation, real-time PCR for the endogenous $\beta$-actin gene was performed according to Manna et al. ${ }^{21}$ with the primers F-5' -dCTGGCACCACACCTTCTACAA-3' and R-5'-dGCCTCGGTCAGCAGCA-3' and the hydrolysis probe 5'-CCACGCGCAGCTCG-3' following a previous protocol ${ }^{21}$. Amplification was performed using a LightCycler ${ }^{\circledR} 480$ II thermocycler (Roche, Rotkreuz, Switzerland). The standard reaction curve was obtained using canine DNA in a ten-fold serial dilution. The DNA concentration was estimated by measuring the absorbance at 260 and $280 \mathrm{~nm}$ in a DS- $11^{\circledR}$ spectrophotometer (DeNovix Inc. Wilmington, DE, USA). Sterilized ultrapure water was used as the negative control.

\section{Leishmania spp. DNA amplification and sequencing}

Samples were tested using a conventional PCR targeting the Leishmania spp. internal transcribed spacer 1 (ITS-1) region of a ribosomal DNA (rDNA) ${ }^{22}$ with primers LITSR (5'-CTGGATCATTTTCCGATG-3') and L5-8S (5'-TGATACCACTTATCGCACTT-3'), generating a DNA fragment of 300 to 350 base pairs (bp) depending on the Leishmania species. The reaction mixtures consisted of $1 \mathrm{U}$ of Platinum ${ }^{\circledR}$ Taq DNA polymerase (Invitrogen, Thermo Fisher Scientific, Waltham, MA, USA), $14.65 \mu \mathrm{L}$ of ultrapure water, $1 \mathrm{X}$ of PCR buffer, $1.5 \mathrm{mM} \mathrm{MgCl}$, $200 \mu \mathrm{M}$ dNTPs (dATP, dCTP, dGTP, and dTTP), 12.5 pmol of each primer, and $2.5 \mu \mathrm{L}$ of extracted DNA from blood. The thermal cycling conditions consisted of $95{ }^{\circ} \mathrm{C}$ for 4 min, followed by 35 cycles at $95{ }^{\circ} \mathrm{C}$ for $30 \mathrm{~s}, 53{ }^{\circ} \mathrm{C}$ for $30 \mathrm{~s}, 72{ }^{\circ} \mathrm{C}$ for $1 \mathrm{~s}$, and $72{ }^{\circ} \mathrm{C}$ for $5 \mathrm{~min}$. The DNA sample of L. amazonensis (IFLA/BR/1967/ph8) provided by the Leishmaniasis Laboratory of the Oswaldo Cruz Institute (FIOCRUZ), Rio de Janeiro, and sterilized ultrapure water were used as positive and negative controls, respectively.

After the amplification product detection through electrophoresis on a $1.5 \%$ agarose gel, the PCR products were excised from the gel and purified using the Illustra ${ }^{\mathrm{TM}}$ GFX PCR DNA and Gel Band Purification Kit (GE 
Healthcare Life Sciences, Little Chalfont, UK), according to the manufacturer's instructions. DNA sequencing was performed using $20 \mathrm{ng} / \mu \mathrm{L}$ of purified PCR products and $5 \mu \mathrm{M}$ of each primer at the DNA Sequencing Service of the Human Genome and Stem Cell Research Center (HUG-CELL), Institute of Biology (IB), University of Sao Paulo (USP), Sao Paulo, Brazil.

Chromatograms obtained with the forward and reverse primers were assembled in the Sequence Scanner Software version 2.0 (Applied Biosystems, Thermo Fisher Scientific, Waltham, MA, USA) for their integrity. Next, the sequences were aligned in the Clustal W software (available in BioEdit Sequence Alignment Editor software, version 7.1.11, Ibis Biosciences, Carlsbad, CA, USA). The obtained consensus sequence was subjected to the Basic Local Alignment Search Tool (BLAST) for the alignment with sequences available in the GenBank database. Species identification of Leishmania spp. was considered correct when the sequences showed over $98 \%$ identity for at least $99 \%$ of the analyzed sequence.

\section{RESULTS}

All samples in this study were positive for the endogenous $\beta$-actin gene, confirming the quality of DNA extraction protocol. Regarding molecular analyses, $1.87 \%$ $(2 / 107)$ of the horses and $8.33 \%$ (3/36) of the donkeys were PCR-positive for the amplified ITS-1 region of Leishmania spp. (Figure 1, Table 1) and submitted to DNA sequencing (Table 2).

The sequencing and BLAST search in the GenBank database showed two horses with $\geq 98,56 \%$ identity with L. infantum ITS-1 sequences (similarity with sequences MN412822.1 and MN648767.1) (Table 2). Regarding the donkeys, sequences from three animals revealed $100 \%$ identity with $L$. infantum ITS-1 sequences (similarity with sequences MN648768.1 and MN648764.1) (Table 2).

\section{DISCUSSION}

Since the first report on Leishmania spp. infection in

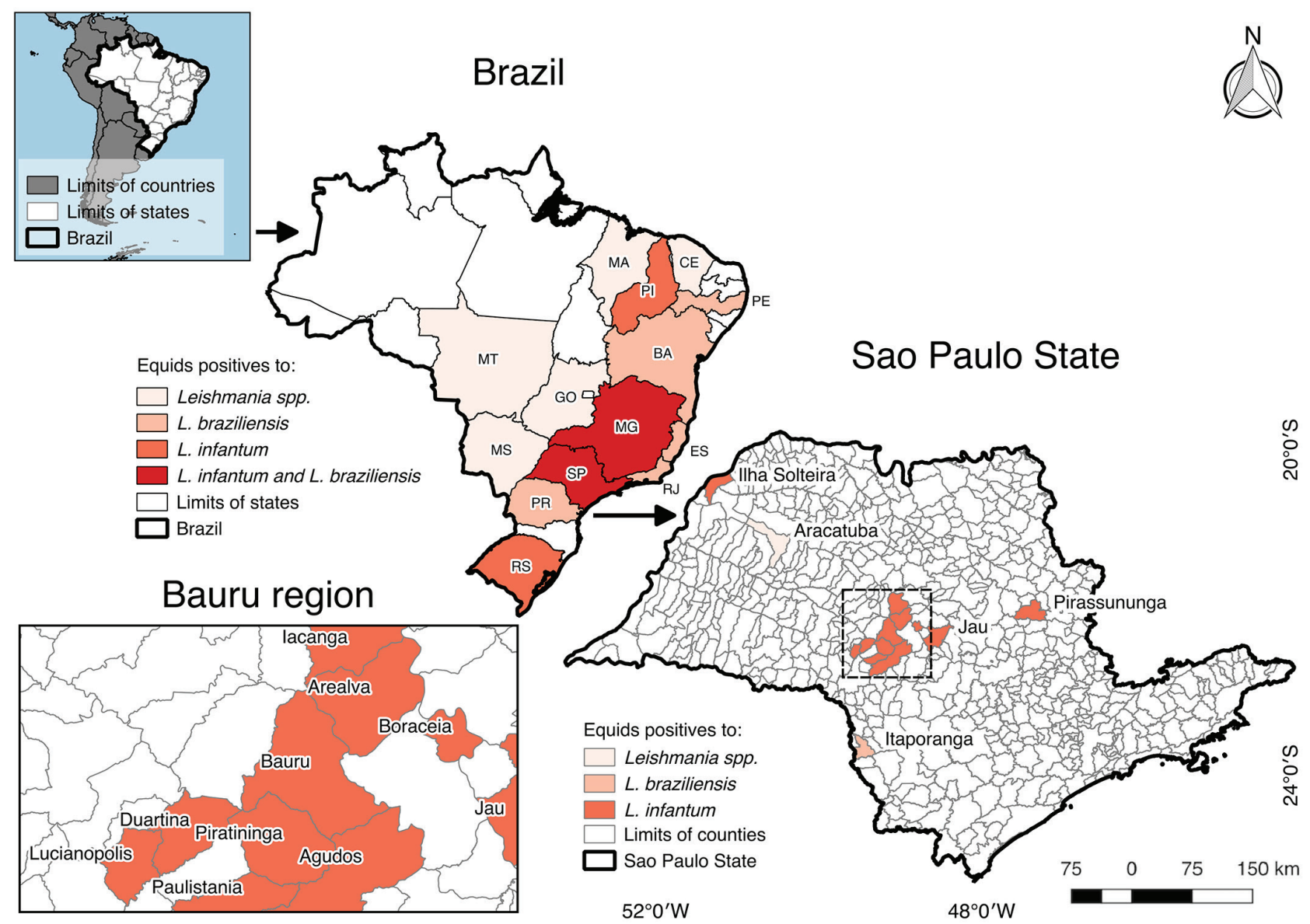

Figure 1 - Equids that are positive to Leishmania spp., described by epidemiological surveys from Brazil and Sao Paulo State. Illustrative map based on twenty articles published in peer reviewed scientific journals between 1959 and 2019 , and results from the present study. 
Table 1 - Epidemiological survey studies on leishmaniasis in equids in counties of Sao Paulo State, Brazil.

\begin{tabular}{|c|c|c|c|c|c|c|c|c|c|}
\hline References & Municipality & Animals & $\begin{array}{l}\text { Clinical } \\
\text { signs }\end{array}$ & $\begin{array}{l}\text { IFAT } \\
(\%)\end{array}$ & $\begin{array}{c}\text { ELISA } \\
(\%)\end{array}$ & $\begin{array}{c}\text { PCR } \\
\text { (DNA target) } \\
(\%)\end{array}$ & $\begin{array}{l}\text { Parasitological } \\
\text { detection* }\end{array}$ & Isolation & $\begin{array}{l}\text { Sequencing } \\
\text { (\% identity) }\end{array}$ \\
\hline $\begin{array}{l}\text { Yoshida } \\
\text { et al. }{ }^{12}\end{array}$ & Itaporanga & 1 & Present & - & - & - & $100 \%$ & L. braziliensis ${ }^{\dagger}$ & - \\
\hline \multirow{9}{*}{$\begin{array}{l}\text { Villalobos } \\
\text { et al..24 }\end{array}$} & Agudos & 16 & - & $12.50 \%$ & - & - & - & - & - \\
\hline & Arealva & 6 & - & $33.33 \%$ & - & - & - & - & - \\
\hline & Bauru & 30 & - & $46.67 \%$ & - & - & - & - & - \\
\hline & Boraceia & 6 & - & $50.0 \%$ & - & - & - & - & - \\
\hline & Duartina & 9 & - & $22.22 \%$ & - & - & - & - & - \\
\hline & lacanga & 2 & & $50.0 \%$ & - & - & & & \\
\hline & Lucianopolis & 10 & - & $50.0 \%$ & - & - & - & - & - \\
\hline & Paulistania & 6 & - & $50.0 \%$ & - & - & - & - & - \\
\hline & Piratininga & 15 & - & $53.33 \%$ & - & - & - & - & - \\
\hline $\begin{array}{l}\text { Feitosa } \\
\text { et al. }{ }^{25}\end{array}$ & Araçatuba & 466 & - & - & $14.59 \%$ & - & - & - & - \\
\hline $\begin{array}{l}\text { Benassi } \\
\text { et al. }{ }^{18}\end{array}$ & Ilha Solteira & 40 & Absence & $2.50 \%$ & - & $15 \%($ L. infantum $)$ & - & - & $\begin{array}{l}99.3 \% \\
\text { L. infantum } \\
\end{array}$ \\
\hline \multirow{2}{*}{$\begin{array}{l}\text { In this } \\
\text { study }\end{array}$} & Pirassununga & 107 & - & - & - & $\begin{array}{c}1.87 \% \\
\text { (Leishmania spp.) }\end{array}$ & - & - & $\begin{array}{l}\geq 98,5 \% \\
\text { L. infantum }\end{array}$ \\
\hline & Jau & 36 & - & - & - & $\begin{array}{c}8.33 \% \\
\text { (Leishmania spp.) }\end{array}$ & - & - & $\begin{array}{c}100 \% \\
\text { L. infantum }\end{array}$ \\
\hline
\end{tabular}

*Visualization by microscopy from cytology, histology or imprint of lesions; tbased on zymodeme and serodeme analysis

horses in South America, some epidemiological surveys have shown positive equids to Leishmania spp. by parasitological, molecular and serological methods in Brazil (Figure 1) 4-12,14,18,23-31.

Regarding Sao Paulo State, Yoshida et al. ${ }^{12}$ reported an equine infected by $L$. braziliensis in a CL endemic area of the State (Itaporanga city) (Figure 1, Table 1). Additionally, in Bauru city region, where CL and VL are endemic, $40 \%$ of tested animals were seropositive for L. infantum (Figure 1, Table 1$)^{24}$. According to Feitosa et al. ${ }^{25}, 14.59 \%$ of the equines sampled presented antibodies against Leishmania spp. in other VL endemic areas of the State (Figure 1, Table 1). The first case of $L$. infantum DNA detection in horses in Sao Paulo State was reported by Benassi et al.$^{18}$ in Ilha Solteira city, which is also a VL endemic area (Figure 1, Table 1). Herein, we performed an epidemiological molecular survey in horses from Pirassununga (CL endemic area) and in donkeys from Jau (CL and VL endemic areas), both cities located in Sao Paulo State, Brazil. In both cities, positive animals to $L$. infantum DNA by PCR were found (Figure 1, Table 1, Table 2).

The best interpretation of these findings is that equids' populations of these leishmaniases endemic areas are in close contact with the parasite. Contact favored by the opportunistic feeding habits of Lutzomyia longipalpis
(VL competent vector), which can feed on a wide variety of vertebrates ${ }^{32}$. Studies on the feed blood source of $L u$. longipalpis showed that horses and donkeys can be used as a blood source ${ }^{32,33}$. According to Oliveira-Pereira et $a l .^{34}$, horses were not a preferred source of blood but were frequently baited by Phlebotomine sandflies, suggesting the need to investigate this species as a possible reservoir.

To the best of our knowledge, this is the first report on the finding of $L$. infantum DNA in donkeys blood samples in Brazil. These animals are from Jau, an important VL endemic area of Sao Paulo State (Figure 1). This finding confirms that equids are exposed to and may be infected by $L$. infantum in VL endemic areas ${ }^{35}$, since they usually live in contact with infected VL vector ${ }^{36}$.

However, despite being an important CL endemic area, VL is not endemic in Pirassununga. In this city, we found two horses with $L$. infantum DNA in blood samples (Figure 1, Table 1, Table 2). It is important to highlight that we cannot exclude the possibility that these animals could have been imported from other regions where VL is endemic. Particularly, the intense movement of equids between regions of different endemicities could be a risk factor for the introduction of leishmaniasis in non-endemic $\operatorname{areas}^{20,33}$. One cat and one cattle that were positive to L. infantum by PCR were also reported in this county ${ }^{15,37}$. 
Table 2 - Leishmania species identification from PCR-positive blood samples, by sequencing of ITS-1 rDNA.

\begin{tabular}{|c|c|c|c|c|c|c|}
\hline Animal & Species & Consensus & Size $^{\star}$ & $\begin{array}{l}\text { Query } \\
\text { cover }\end{array}$ & Identity & $\begin{array}{l}\text { BLAST search } \\
\text { (GenBank sequence } \\
\text { similarity) }\end{array}$ \\
\hline 1 & Donkey & $\begin{array}{l}\text { >Consensus } 1 \\
\text { CAGTCATCCATCGCGACACGTTATGTGAGCCGTTAT } \\
\text { CCACACACGCACCCACCCCGCCAAAAACCGAAAC } \\
\text { GCCGTATATTTTTTGTATAAACGGACATTTT }\end{array}$ & $101 \mathrm{bp}$ & $99 \%$ & $100 \%$ & $\begin{array}{c}\text { L. infantum } \\
\text { (MN648768.1) }\end{array}$ \\
\hline 2 & Donkey & $\begin{array}{l}\text { >Consensus } 2 \\
\text { TCTGGATCATTTTCCGATGATTACACCCAAAAAAC } \\
\text { ATATACAACTCGGGGAGACCTATGTATATATATGTAGG } \\
\text { CCTTTCCCACATACACAGCAAAGTTTTGTACTCAAAA } \\
\text { TTTGCAGTAAAAAAAAGGCCGATCGACGTTATAACG } \\
\text { CACCGCCTATACAAAAGCAAAAATGTCCGTTTATACA } \\
\text { AAAAATATACGGCGTTTCGGTTTTTGGCGGGGTGGG } \\
\text { TGCGTGTGTGGATAACGGCTCACATAACGTGTCGCG } \\
\text { ATGGATGAC }\end{array}$ & $264 \mathrm{bp}$ & $100 \%$ & $100 \%$ & $\begin{array}{l}\text { L. infantum } \\
\text { (MN648764.1) }\end{array}$ \\
\hline 3 & Donkey & $\begin{array}{l}\text { >Consensus } 3 \\
\text { TCTGGATCATTTTCCGATGATTACACCCAAAAAACAT } \\
\text { ATACAACTCGGGGAGACCTATGTATATATATGTAGGC } \\
\text { CTTTCCCACATACACAGCAAAGTTTTGACTCAAAA } \\
\text { TTTGCAGTAAAAAAAAGGCCGATCGACGTTATAACG } \\
\text { CACCGCCTATACAAAAGCAAAAATGTCCGTTTATAC } \\
\text { AAAAAATATACGGCGTTTCGGTTTTTGGCGGGGT } \\
\text { GGGTGCGTGTGTGGATAACGGCTCACATAACGTG } \\
\text { TCGCGATGGATGAC }\end{array}$ & 264 bp & $100 \%$ & $100 \%$ & $\begin{array}{l}\text { L. infantum } \\
\text { (MN648764.1) }\end{array}$ \\
\hline 4 & Horse & $\begin{array}{l}\text { >Consensus } 4 \\
\text { TCTGGATCATTTTCCGATGATTACACCCAAAAAAC } \\
\text { ATATACAACTCGGGGAGACCTATGTATATATATGTAG } \\
\text { GCCTTTCCCACATACACAGCAAAGTTTTTACTC } \\
\text { AAAATTTGCAGTAAAAAAAAGGCCGATCGACGTT } \\
\text { ATAACGCACCGCCTATACAAAAGCAAAATGTCCG } \\
\text { TTTATACAAAAAATATACGGCGTTTCGGTTTTTGG } \\
\text { CGGGGTGGGTGCGTGTGTGGATAACGGCTCAC } \\
\text { ATAACGTGTCGCGATGGATGAC }\end{array}$ & $263 b p$ & $100 \%$ & $99.62 \%$ & $\begin{array}{l}\text { L. infantum } \\
\text { (MN412822.1) }\end{array}$ \\
\hline 5 & Horse & $\begin{array}{l}\text { >Consensus } 5 \\
\text { ATGTATATATATGTAGGCCTTTCCCACATACACAGC } \\
\text { AAAGTTTTGTACTCAAAATTTGCAGTAAAAAAAAG } \\
\text { GCCRATCGACGTTATAMCGCACCSCCTATACAAA } \\
\text { AGCAAAAATGTCCGTTTATACAAAAAATATACGGC } \\
\text { GTTTCGGTTTTTGGCGGGGTGGGTGCGTGTGT } \\
\text { GGATAACGGCTCACATAACGTGTCGCGATGGATGAC }\end{array}$ & $208 b p$ & $100 \%$ & $98.56 \%$ & $\begin{array}{c}\text { L. infantum } \\
\text { (MN648767.1) }\end{array}$ \\
\hline
\end{tabular}

*in base pairs (bp)

Somehow, more epidemiological surveys on the equids' population of the county together with entomological surveys are fundamental for measuring the magnitude of these findings in this non-VL endemic region.

It is important to consider that L. infantum DNA found in the blood of equids does not imply them as VL reservoirs but suggests that they may be accidental hosts ${ }^{26,38}$. When donkeys were challenged with promastigotes of L. infantum and followed-up for 12 months, Cerqueira et $a l .{ }^{39}$ concluded that donkeys were able to overcome the experimental Leishmania infection and did not infect Lu. longipalpis vector under laboratory conditions. Consequently, they cannot be considered an important reservoir in the epidemiological chain of transmission of L. infantum, although they represent an important blood source for the vector and their proliferation. Nevertheless, no other study regarding xenodiagnosis in equids has been performed so far. In addition, the natural role of equids in the leishmaniases transmission has not yet been demonstrated or refuted ${ }^{19,29}$, and the impact of these animals on leishmaniases epidemiological cycles remains unclear ${ }^{20}$.

Hence, we recognize the urgency and importance of investigating the equids' populations to improve the understanding of the epidemiology of $L$. infantum infection in these animals ${ }^{19,29}$. L. infantum DNA detection in the blood samples of horses and donkeys suggests that these 
animals can be infected by the parasite in the studied areas. In addition, our results suggest that $L$. infantum potentially circulates among equids from VL and non-VL endemic areas of Sao Paulo State, Brazil.

\section{CONCLUSION}

L. infantum DNA detection in blood samples of horses and donkeys by PCR in non-VL and VL endemic areas of Sao Paulo State indicates that these animals can be infected by the parasite.

\section{ACKNOWLEDGMENTS}

We would like to thank all horse owners for allowing their animals to participate in this epidemiological molecular survey.

\section{AUTHORS' CONTRIBUTIONS}

Conceptualization: JAFL, BT, TMFSO; data curation: BT, JAFL; formal analysis: JAFL, RMS, BT, TMFSO; funding acquisition: BT, TMFSO; investigation: BT, JAA, JCB, RAB; methodology: BT, JAA, JAFL, JCB, RAB, HLF, LKB; project administration: TMFSO; software: JAFL, RMS, HLF, LKB; supervision: HLF, LKB, RAB, TMFSO; writing-original draft: JAFL, GV, TMFSO; writing-review \& editing: JAFL, GV, TMFSO, RMS, LKB, HLF, RAB.

\section{ETHICAL STATEMENT}

The present study was approved by the Ethics Committee for the Use of Animals at the Faculty of Animal Science and Food Engineering of the University of Sao Paulo (under the processes $\mathrm{N}^{\circ} 3615240516$ and 8335160218 ) and was performed in compliance with national guidelines. All horse owners consented to have their animals sampled.

\section{FUNDING}

This research received financial support provided by the Sao Paulo Research Foundation (FAPESP) under project No 2013/19821-4.

\section{REFERENCES}

1. World Health Organization. Leishmaniasis in high-burden countries: an epidemiological update based on data reported in 2014. Wkly Epidemiol Rec. 2016;91:287. [cited 2020 Dec 14]. Available from: https://www.who.int/leishmaniasis/resources/ who_wer9122/en/
2. Ashford RW. The leishmaniases as emerging and reemerging zoonoses. Int J Parasitol. 2000;30:1269-81.

3. Mazza S. Leishmaniasis cutánea en el caballo y nueva observación de la misma en el perro. Bol Inst Clin Quir. 1927;3:462-4.

4. Vexenat JA, Barretto AC, Rosa AC, Sales CC, Magalhães AV. Infecção natural de Equus asinus por Leishmania braziliensis braziliensis - Bahia, Brazil. Mem Inst Oswaldo Cruz. 1986;81:237-8.

5. Aguilar CM, Rangel EF, Grimaldi-Filho G, Momem H. Human, canine and equine leishmaniasis caused by Leishmania braziliensis braziliensis in an endemic area in the State of Rio de Janeiro. Mem Inst Oswaldo Cruz. 1987;82:143.

6. Falqueto A, Varejão JB, Sessa PA. Cutaneous leishmaniasis in a horse (Equus caballus) from enfemic area in the state of Espírito Santo, Brazil. Mem Inst Oswaldo Cruz. 1987;82:443.

7. Oliveira-Neto MP, Pirmez C, Rangel E, Schubach A, Grimaldi Júnior G. An outbreak of american cutaneous leishmaniasis (Leishmania braziliensis braziliensis) in a periurban area of Rio de Janeiro city, Brazil: clinical and epidemiological studies. Mem Inst Oswaldo Cruz. 1988;83:427-35.

8. Follador I, Araujo C, Cardoso MA, Tavares-Neto J, Barral A, Miranda JC, et al. Surto de leishmaniose tegumentar americana em Canoa, Santo Amaro, Bahia, Brasil. Rev Soc Bras Med Trop. 1999;32:497-503.

9. Brandão-Filho SP, Brito ME, Carvalho FG, Ishikawa EA, Cupolillo E, Floeter-Winter L, et al. Wild and synanthropic hosts of Leishmania (Viannia) braziliensis in the endemic cutaneous leishmaniasis locality of Amaraji, Pernambuco State, Brazil. Trans R Soc Trop Med Hyg. 2003;97:291-6.

10. Vedovello Filho D, Jorge FA, Lonardoni MV, Teodoro U, Silveira TG. American cutaneous leishmaniasis in horses from endemic areas in the north-central Mesoregion of Paraná state, Brazil. Zoonoses Public Health. 2008;55:149-55.

11. Truppel JH, Otomura F, Teodoro U, Massafera R, CostaRibeiro MC, Catarino CM, et al. Can equids be a reservoir of Leishmania braziliensis in endemic areas? PLoS One. 2014;9:e93731.

12. Yoshida EL, Correa FM, Marques SA, Stolf HO, Dillon NL, Momen $\mathrm{H}$, et al. Human, canine and equine (Equus caballus) leishmaniasis due to Leishmania braziliensis ( $=\mathrm{L}$. braziliensis braziliensis) in the south-west region of São Paulo state, Brazil. Mem Inst Oswaldo Cruz. 1990;85:133-4.

13. Bonfante-Garrido R, Meléndez E, Barroeta S, Mejia-de-Alejos MA, Momen H, Cupolillo E, et al. Cutaneous leishmaniasis in western Venezuela caused by infection with Leishmania venezuelensis and L. braziliensis variants. Trans R Soc Trop Med Hyg. 1992;86:141-8.

14. Soares IR, Silva SO, Moreira FM, Prado LG, Fantini P, Maranhão RP, et al. First evidence of autochthonous cases of Leishmania (Leishmania) infantum in horse (Equus caballus) in the Americas and mixed infection of Leishmania 
infantum and Leishmania (Viannia) braziliensis. Vet Parasitol. 2013;197:665-9.

15. Benassi JC, Benvenga GU, Ferreira HL, Pereira VF, Keid LB, Soares R, et al. Detection of Leishmania infantum DNA in conjunctival swabs of cats by quantitative real-time PCR. Exp Parasitol. 2017;177:93-7.

16. Koehler K, Stechele M, Hetzel U, Domingo M, Schönian G, Zahner $\mathrm{H}$, et al. Cutaneous leishmaniosis in a horse in southern Germany caused by Leishmania infantum. Vet Parasitol. 2002;109:9-17.

17. Gama A, Elias J, Ribeiro AJ, Alegria N, Schallig HD, Silva F, et al. Cutaneous leishmaniosis in a horse from northern Portugal. Vet Parasitol. 2014;200:189-92.

18. Benassi JC, Benvenga GU, Ferreira HL, Soares RM, Silva DT, Pereira VF, et al. Molecular and serological detection of Leishmania spp. in horses from an endemic area for canine visceral leishmaniasis in southeastern Brazil. Pesq Veter Bras. 2018;38:1058-63.

19. Limeira CH, Alves CJ, Azevedo SS, Santos CS, Melo MA, Soares $\mathrm{RR}$, et al. Clinical aspects and diagnosis of leishmaniasis in equids: a systematic review and meta-analysis. Rev Bras Parasitol Vet. 2019;28:574-81.

20. Mhadhbi M, Sassi A. Infection of the equine population by Leishmania parasites. Equine Vet J. 2020;52:28-33.

21. Manna L, Reale S, Viola E, Vitale F, Manzillo VF, Michele PL, et al. Leishmania DNA load and cytokine expression levels in asymptomatic naturally infected dogs. Vet Parasitol. 2006;142:271-80.

22. el Tai NO, Osman OF, el Fari M, Presber W, Schönian G. Genetic heterogeneity of ribosomal internal transcribed spacer in clinical samples of Leishmania donovani spotted on filter paper as revealed by single-strand conformation polymorphisms and sequencing. Trans R Soc Trop Med Hyg. 2000;94:575-9.

23. Barbosa-Santos EG, Marzochi MC, Urtado W, Queirós F, Chicarino J, Pacheco RS. Leishmaniasis disseminated by Leishmania braziliensis in a mare (Equus cabalus) immunotherapy and chemotherapy assays. Mem Inst Oswaldo Cruz. 1994;89:217-20.

24. Villalobos EM, Carvalho PR, Lara MC, Marques EC, Souza MC, Felicio PS, et al. Prevalence of immune response of healthy equines with antibodies anti Leishmania chagasi in an endemic area of leishmaniasis. Middle-East J Sci Res. 2010;5:520-34.

25. Feitosa FL, Leal J, Mendes LC, Peiró JR, Perri SH, Lima VM, et al. Estudo soroepidemiológico de leishmaniose em equinos na região de Araçatuba-SP, Brasil, área endêmica para leishmaniose visceral. Braz J Vet Res Anim Sci. 2012;49:500-2.

26. Magalhães NA, Ribeiro FH, Oliveira EG, Martins AP, Sá Junior JA, Silva LS, et al. Equídeos infectados por Leishmania (Leishmania) infantum na área endêmica de Teresina, Piauí, Brasil. Rev Bras Cien Vet. 2016;23:163-7.
27. Evers F, Ferreira FP, Navarro IT, Mitsuka-Breganó R, Pagliari S, Monica TC, et al. Presence of anti-Leishmania spp. antibodies in slaughter horses in Brazil. Semina Cien Agr. 2017;38:3921-6.

28. Oliveira PM, Garcia F, Evers F, Barbosa VM, Obando DC, Nasciutti NR, et al. Seroepidemiology of Leishmania spp. in equids from Uberlândia, Minas Gerais, Brazil. Cien Rural. 2017;47:e20160697.

29. Escobar TA, Dowich G, Santos TP, Zuravski L, Duarte CA, Lübeck I, et al. Assessment of Leishmania infantum infection in equine populations in a canine visceral leishmaniosis transmission area. BMC Vet Res. 2019;15:381.

30. Duarte R, Theophilo FA, Marzochi MC, Ferreira FC, Oliveira MR, Mendes FA, et al. Sorologia para leishmaniose em eqüinos no município do Rio de Janeiro. Bol Divulg Tec Cien. 2000;2:8.

31. Ferreira FP, Caldart ET, Brito DR, Chaves DP, Garcia JL, Navarro IT. "Baixadeiros" horses: prevalence of anti-Trypanosoma spp. and anti-Leishmania spp. antibodies. Cien Anim Bras. 2018;19:e-51522.

32. Barata RA, França-Silva JC, Mayrink W, Silva JC, Prata A, Lorosa ES, et al. Aspectos da ecologia e do comportamento de flebotomíneos em área endêmica de leishmaniose visceral, Minas Gerais. Rev Soc Bras Med Trop. 2005;38:421-5.

33. Guimarães-e-Silva AS, Silva SO, Silva RC, Pinheiro VC, Rebêlo JM, Melo MN. Leishmania infection and blood food sources of phlebotomines in an area of Brazil endemic for visceral and tegumentary leishmaniasis. PLoS One. 2017;12:e0179052.

34. Oliveira-Pereira YN, Moraes JL, Lorosa ES, Rebêlo JM. Preferência alimentar sanguínea de flebotomíneos da Amazônia do Maranhão, Brasil. Cad Saude Publica. 2008;24:2183-6.

35. Lopes AP, Sousa S, Dubey JP, Ribeiro AJ, Silvestre R, Cotovio $\mathrm{M}$, et al. Prevalence of antibodies to Leishmania infantum and Toxoplasma gondii in horses from the north of Portugal. Parasit Vectors. 2013;6:178.

36. Nardoni S, Altomonte I, Salari F, Martini M, Mancianti F. Serological and molecular findings of Leishmania infection in healthy donkeys (Equus asinus) from a canine leishmaniosis endemic focus in Tuscany, Italy: a preliminary report. Pathogens. 2019;8:99.

37. Vioti G, Leonel JA, Lemes KM, Pereira VF, Ferreira HL, Keid LB, et al. Molecular detection of Leishmania spp. in cattle from Brazil by means of PCR using internal transcribed spacer 1 . Rev Bras Parasitol Vet. 2019;28:303-5.

38. Kouam MK, Diakou A, Kantzoura V, Papadopoulos E, Gajadhar AA, Theodoropoulos G. A seroepidemiological study of exposure to Toxoplasma, Leishmania, Echinococcus and Trichinella in equids in Greece and analysis of risk factors. Vet Parasitol. 2010;170:170-5.

39. Cerqueira EJ, Sherlock I, Gusmão A, Barbosa Junior AA, Nakatani M. Inoculação experimental de Equus asinus com Leishmania chagasi Cunha \& Chagas, 1937. Rev Soc Bras Med Trop. 2003;36:695-701 